\title{
Piribedil-induced Reversible Pisa Syndrome in a Patient with Lewy Body Dementia
}

\author{
Lewy Cisimcikli Demans Tanılı Bir Hastada Piribedil ile Tetiklenen Geri Dönüşümlü \\ Pisa Sendromu
}

\author{
(1) Murat Mert Atmaca, (1) Başar Bilgiç, (1) Haşmet Hanağası \\ Istanbul University, Istanbul Faculty of Medicine Hospital, Clinic of Neurology, Istanbul, Turkey
}

\begin{abstract}
Pisa syndrome (PS) has been described for the first time as a side effect of neuroleptic treatment in patients with schizophrenia. After its first description, PS was reported in patients on dopamine receptor antagonists, cholinesterase inhibitors, and antidepressants. PS was also associated with neurodegenerative diseases such as Alzheimer's disease, multiple system atrophy, and dementia of Lewy bodies (DLB). Dopaminergic treatment in Parkinson's disease (PD) may also lead to PS in PD patients. Here, we report a patient with probable DLB who developed PS after the initiation of piribedil treatment. After cessation of piribedil, PS disappeared entirely. We want to highlight that PS related to dopaminergic treatment may be reversible, and like other dopamine agonists, piribedil has the potential to cause PS in patients with parkinsonism.
\end{abstract}

Keywords: Parkinsonism, Pisa syndrome, piribedil, dopamine agonists

\section{$\ddot{O} \mathbf{z}$}

Pisa sendromu (PS) ilk kez şizofrenili hastalarda nöroleptik tedavinin yan etkisi olarak tarif edilmiştir. Zamanla bu postural bozukluk, dopamin reseptör antagonistleri, kolinesteraz inhibitörleri ve antidepresan tedavi alan hastalarda; Alzheimer hastalığ1, multi sistem atrofi, Lewy cisimcikli demans (LCD) gibi nörodejeneratif hastalıklarda ve son olarak da dopaminerjik tedavi verilen Parkinson hastalığ LCD tanısı konan ve piribedil tedavisi başlandıktan sonra PS gelişen bir hasta sunulmuştur. Piribedil kesildikten sonra PS tamamen düzelmiştir. Bu yazıda; dopaminerjik tedavi ile ilişkili PS'nin geri dönüşümlü olabildiğinin ve piribedilin PH'de PS'ye yol açabileceğinin altını çizmek istedik.

Anahtar Kelimeler: Parkinsonizm, Pisa sendromu, piribedil, dopamin agonistleri

\section{Introduction}

Pisa syndrome (PS), camptocormia, antecollis, and scoliosis are frequent and disabling postural deformities seen in patients with Parkinson's disease (PD) and atypical parkinsonism (1). PS, also known as "pleurothotonus," is a rare clinical entity due to various conditions, characterized by lateral bending of the trunk, which resembles the appearance of the ancient Pisa Tower. Ekbom first described it as an adverse effect of neuroleptic treatment in patients with schizophrenia (2). After the initial report, several treatments including selective serotonin reuptake inhibitors, tricyclic antidepressants, cholinesterase inhibitors, lithium, antiemetics, benzodiazepines, and tiapride were reported to induce PS (3).

PS may appear in the course of PD following the initiation of dopaminergic treatments or spontaneously (4). PS has also been reported in neurodegenerative disorders, including Alzheimer's disease, multiple system atrophy, and dementia of Lewy bodies (DLB) (5). A lateral flexion at least $10^{\circ}$, which resolves with passive mobilization or supine positioning, has been suggested as a diagnostic criterion for PS, although there is no consensus (1). This finding distinguishes PS from scoliosis because scoliosis does

This study was presented as an e-poster presentation at the $54^{\text {th }}$ National Neurology Congress, which took place in the Rixos Sungate Otel Antalya between November 30 and December 6, 2018 (EP-236, page 230 in the abstract book).

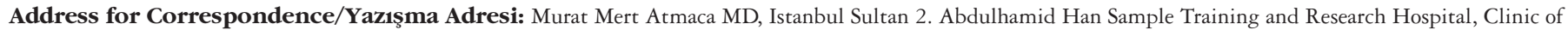
Neurology, Istanbul, Turkey

Phone: +90 5332764868 E-mail: drmuratmertatmaca@hotmail.com ORCID: orcid.org/0000-0003-2048-4930

Received/Geliş Tarihi: 13.05.2019 Accepted/Kabul Tarihi: 24.02.2021

${ }^{\circ}$ Copyright 2021 by Turkish Neurological Society

Turkish Journal of Neurology published by Galenos Publishing House. 
not (or partially) resolve in the supine position. However, it should be kept in mind that PS may coexist with scoliosis. Camptocormia also completely resolves in the supine position, but there is severe flexion (more than $45^{\circ}$ ) of the thoracolumbar spine in the sagittal plane during standing and walking $(5,6)$.

Here, we present a patient with probable DLB who developed PS after the initiation of piribedil treatment.

\section{Case Report}

An 81-year-old female was admitted to the outpatient clinic with gait problems and slowness of movements, which started two years ago. Family members stated a fluctuating and progressive course of impaired cognition mainly involving memory, attention, and executive functions with a duration of two years. No "rapid eye movement" sleep disorder, hallucinations, and orthostatic hypotension were reported. She had urinary incontinence for three years and was on darifenacin treatment. Before admission, she was diagnosed as having "dementia and parkinsonism" and was put on donepezil $5 \mathrm{mg} / \mathrm{d}$, levodopa (L-dopa) + benserazide 3x125 $\mathrm{mg} / \mathrm{d}$, and primidone $125 \mathrm{mg} / \mathrm{d}$ in another outpatient clinic. In her medical history, she had hypertension, chronic obstructive pulmonary disease, and depression, and she was on trandolapril, tiotropium bromide monohydrate, and escitalopram. In her neurologic examination, she had bilateral rigidity and bradykinesia, predominantly on the left side. The most prominent finding was marked resting and postural tremor in both sides, predominantly on the right upper and lower extremities. She was walking leaning forward in small steps with less associated movements of the left arm. Myerson sign was positive, and palmomental reflexes were negative. The Hoehn and Yahr (H\&Y) scale score was 3.

Cranial magnetic resonance (MR) imaging of the brain revealed atrophy in the bilateral hippocampus, cerebellum, and frontoparietal areas. There were moderate periventricular whitematter lesions and mild enlargement of the lateral ventricles. The neuropsychological evaluation showed impairment in memory, executive and visuospatial functions, and progression in cognitive impairment compared with a neuropsychological evaluation performed two years ago. With clinical, neuropsychological, and neuroimaging findings, the patient was diagnosed as having "probable DLB".

For her motor symptoms, the L-dopa + benserazide dosage was increased up to $562.5 \mathrm{mg} / \mathrm{d}$, and rasagiline $1 \mathrm{mg} / \mathrm{d}$ was initiated. After five months, there was no change in her symptoms. Piribedil was started at a dose of $2 \times 25 \mathrm{mg} / \mathrm{d}$. The dosage was planned to be increased to $3 \times 50 \mathrm{mg} / \mathrm{d}$ in 2 weeks. The patient was reevaluated one month later because of the increase in tremor and falls. In the examination, there was a significant bending of the trunk to the left side. PS was considered, and piribedil was stopped. L-dopa + benserazide and rasagiline treatments continued. One month later, the PS disappeared completely. Informed consent was obtained from the patient.

\section{Discussion}

The presented case here was a patient with probable DLB who developed reversible PS after the initiation of piribedil treatment. According to the revised criteria of the fourth consensus report of the DLB Consortium for the clinical diagnosis of probable and possible DLB (6), our patient was diagnosed as having "probable DLB" because she had two core clinical features (fluctuating cognition and all spontaneous cardinal features of parkinsonism including bradykinesia, resting tremor, and rigidity). Also, there was no time gap longer than one year between the appearance of cognitive symptoms and parkinsonism in the patient, compatible with the time pattern of symptomology seen in DLB.

Most studies on the clinical features of PS were performed in patients with PD rather than patients with atypical parkinsonism. There were patients with PD reported in the literature who developed PS after the initiation and modification of dopamine agonists, including pergolide, pramipexole, ropinirole, piribedil, and L-dopa combinations $(4,7)$. In a case series including eight patients with PD who developed PS after the modification of the dopaminergic treatment, it was reported that PS appeared after a certain period ( 15 days- 3 months). In this study, the majority of the patients developed PS after increasing the dose of the dopaminergic treatment; however, only one patient developed PS after dose decrement. PS was reversible and fully disappeared with the modification of dopaminergic treatment in all patients (8). In a cross-sectional multi-center study including a large number of patients with PD, PS was reported in $8.8 \%$ of the patients (4). In that study, PS was found to be associated with older age, longer disease duration, disease severity, lower body mass index, treatment of PD, other medical conditions such as osteoporosis and arthrosis, veering gait, and reduced quality of life.

Our patient was elderly with moderate severity disease ( $\mathrm{H} \& \mathrm{Y}$ score was 3). Because L-dopa treatment with substantial dosage did not improve motor symptoms, including the tremor which was the main disabling symptom for this patient; piribedil, which had the potential to reduce the tremor in patients with PD, was initiated with close follow-up. However, PS developed one month later and the patient leaned away from her dominant side of parkinsonism. PS disappeared completely one month after the discontinuation of piribedil.

In patients with DLB, L-dopa may be used for the treatment of severe motor dysfunction, even L-dopa replacement is less effective in DLB than in PD. In case of unresponsiveness to L-dopa, other medications, including dopamine agonists and monoamine oxidase inhibitors, may be used with caution because they tend to exacerbate the behavioral problems of DLB (9). The case presented here highlights that PS should also be considered as an adverse effect of piribedil treatment in patients with DLB.

There are central mechanisms that play a role in the development of PS. Dopamine exposure as a priming factor may cause PS by leading to an increased response in denervated and sensitized striatum in predisposed patients $(10,11)$. This hypothesis is supported by some studies reporting that patients with PD lean away from their dominant PD side $(7,12)$. However, it was reported that patients could lean towards or lean away from their dominant PD side (almost 1:1), and dopaminergic drug-induced PS was detected in $15 \%$ of patients with PD (4). As a result, the relationship between dopaminergic treatment and the development of PS is uncertain. Body asymmetry due to asymmetric impairment of basal ganglia may predispose patients with PD to PS. However, patients with PD can lead towards or away from the side most affected by PD, which suggests that 
other mechanisms rather than basal ganglia asymmetry should contribute to development of PS (13). Postural control requires the integration of the sensory information including proprioceptive, visual and vestibular inputs. In addition to impairment of proprioceptive (10) and vestibular system (11), a possible deficit in the integration of somatosensory processes was also shown in PS (14). It has been suggested that these deficits worsen with the progression of the disease (13).

There are also peripheral mechanisms proposed for the etiology of PS. Atrophy and fatty degeneration of the trunk muscles, suggesting a localized myopathy of paraspinal muscles, have been shown in MR imaging in patients with PS. These changes are suggested to be related to disuse or denervation secondary to postural abnormality (1). Concomitant factors of PS such as degenerative spinal conditions may contribute to the development of postural deformities by affecting the bone and soft tissue (4). Back pain is frequent in patients with PS, and postural changes to relieve pain in patients with PD may negatively affect the integration of sensory information leading to an abnormal body scheme, which then leads to PS (1). Recently, the lack of inter-muscular coherence of axial muscles was shown in electromyography in PS, which was associated with bradykinesia. According to the authors, their data supported the hypothesis of PS as a clinical sign of bradykinesia (15).

It has been suggested that there are chronic (CT) and subchronic (ST) types of lateral flexion of the trunk in PD. CT presents with mild symptoms, and symptoms gradually increase as the disease progresses. On the other hand, ST shows a rapid progression like PS, and sometimes ST can be induced with the administration of a dopamine agonist (12). It has also been suggested that there are both rigidity and dystonia in ST, whereas there is only dystonia in PS (12).

We reported a patient with probable DLB who developed PS after adjustment of piribedil. Fully recover in PS after cessation of piribedil highlights the importance of checking for postural abnormalities in patients with parkinsonism using dopamine agonists. Discontinuation of the dopaminergic treatment initiated before PS or re-modification of the treatment is recommended before this posture causes permanent changes in the spinal cord and becomes irreversible (12).

\section{Ethics}

Informed Consent: Informed consent was obtained from the patient.
Peer-review: Internally peer-reviewed.

\section{Authorship Contributions}

Surgical and Medical Practices: B.B., H.H., Concept: B.B., H.H., Design: M.M.A., Data Collection or Processing: M.M.A., Analysis or Interpretation: B.B., H.H., Literature Search: M.M.A., Writing: M.M.A.

Conflict of Interest: No conflict of interest was declared by the authors.

Financial Disclosure: The authors declared that this study received no financial support

\section{References}

1. Doherty KM, van de Warrenburg BP, Peralta MC, et al. Postural deformities in Parkinson's disease. Lancet Neurol 2011;10:538-549.

2. Ekbom K, Lindholm H, Ljungberg L. New dystonic syndrome associated with butyrophenone therapy. Z Neurol 1972;202:94-103

3. Suzuki T, Matsuzaka H. Drug-induced Pisa syndrome (pleurothotonus) epidemiology and management. CNS Drugs 2002;16:165-174.

4. Tinazzi M, Fasano A, Geroin C, et al. Pisa syndrome in Parkinson disease: an observational multicenter Italian study. Neurology 2015;85:1769-1779.

5. Tinazzi M, Geroin C, Gandolfi M, et al. Pisa syndrome in Parkinson's disease: an integrated approach from pathophysiology to management. Mov Disord 2016;31:1785-1795.

6. McKeith IG, Boeve BF, Dickson DW, et al. Diagnosis and management of dementia with Lewy bodies: fourth consensus report of the DLB Consortium. Neurology 2017;89:88-100,

7. Galati S, Moller JC, Stadler C. Ropinirole-induced Pisa syndrome in Parkinson disease. Clin Neuropharmacol 2014;37:58-59.

8. Cannas A, Solla P, Floris G, et al. Reversible Pisa syndrome in patients with Parkinson's disease on dopaminergic therapy. J Neurol 2009;256:390-395.

9. Molloy S, McKeith IG, O'Brien JT, Burn DJ. The role of levodopa in the management of dementia with Lewy bodies. J Neurol Neurosurg Psychiatry 2005;76:1200-1203.

10. Castrioto A, Piscicelli C, Perennou D, Krack P, Debu B. The pathogenesis of Pisa syndrome in Parkinson's disease. Mov Disord 2014;29:1100-1107.

11. Vitale C, Marcelli V, Furia T, et al. Vestibular impairment and adaptive postural imbalance in parkinsonian patients with lateral trunk flexion. Mov Disord 2011;26:1458-1463.

12. Yokochi F. Lateral flexion in Parkinson's disease and Pisa syndrome. J Neurol 2006;253(Suppl 7):VII17-VII20.

13. Barone P, Santangelo G, Amboni M, Pellecchia MT, Vitale C. Pisa syndrome in Parkinson's disease and parkinsonism: clinical features, pathophysiology, and treatment. Lancet Neurol 2016;15:1063-1074.

14. Smania N, Corato E, Tinazzi M, et al. Effect of balance training on postural instability in patients with idiopathic Parkinson's disease. Neurorehabil Neural Repair 2010;24:826-834.

15. Formaggio E, Masiero S, Volpe D, et al. Lack of inter-muscular coherence of axial muscles in Pisa syndrome. Neurol Sci 2019;40:1465-1468. 